\title{
Polynucleobacter rarus sp. nov., a free-living planktonic bacterium isolated from an acidic lake
}

Correspondence Martin W. Hahn martin.hahn@oeaw.ac.at

\author{
Martin W. Hahn, ${ }^{1}$ Elke Lang, ${ }^{2}$ Mitsunori Tarao ${ }^{1,3}$ and Ulrike Brandt ${ }^{1}$ \\ ${ }^{1}$ Institute for Limnology, Austrian Academy of Sciences, Mondseestrasse 9, 5310 Mondsee, Austria \\ ${ }^{2} \mathrm{DSMZ}$ - Deutsche Sammlung von Mikroorganismen und Zellkulturen GmbH, Inhoffenstraße 7b, \\ D-38124 Braunschweig, Germany \\ ${ }^{3}$ Institute of Symbiotic Science and Technology, Tokyo University of Agriculture and Technology, \\ Fuchu, Tokyo 183-8509, Japan
}

\begin{abstract}
The heterotrophic, aerobic, facultatively anaerobic under denitrifying conditions, catalase- and oxidase-positive, non-motile strain $\mathrm{MT}-\mathrm{CBb} 6 \mathrm{~A} 5^{\top}$, which was isolated from an acidic lake located in Wisconsin (USA), was characterized. The strain grew on NSY medium over a temperature range of $15-30{ }^{\circ} \mathrm{C}$ and a $\mathrm{NaCl}$ range of $0.0-0.3 \%(\mathrm{w} / \mathrm{v})$. The predominant fatty acids were $\mathrm{C}_{16: 0}, \mathrm{C}_{18: 1} \omega 7 c, 11$-methyl $\mathrm{C}_{18: 1} \omega 7 c$, feature 3 (including $\mathrm{C}_{16: 1} \omega 7 c$ ), and feature 2 (including $\left.\mathrm{C}_{14: 0} 3-\mathrm{OH}\right)$. The DNA G $+\mathrm{C}$ content of the strain was $40.3 \mathrm{~mol} \%$. Phylogenetic analysis as well as strong similarities in phenotypic and chemotaxonomic traits indicated the affiliation with the genus Polynucleobacter. 16S rRNA gene sequence similarity values with the two described species of the genus Polynucleobacter ranged from 95.6 to $96.0 \%$. The strain differs from the two described species of the genus Polynucleobacter in the ability to assimilate oxalic and glycolic acids, and in the presence of the fatty acids $C_{15: 1} \omega 8 \mathrm{c}$ and $\mathrm{C}_{16: 0} 3-\mathrm{OH}$ as well as in quantitative differences in fatty acid composition. It has to be assumed that the strain shares with other free-living bacteria of the genus Polynucleobacter a planktonic lifestyle in the water column of freshwater habitats. Based on the phylogeny revealed and the chemotaxonomic and phenotypic differences from Polynucleobacter necessarius and Polynucleobacter cosmopolitanus, we propose to establish the novel species Polynucleobacter rarus sp. nov. with the type strain MT-CBb6A5 ${ }^{\top}\left(=\mathrm{DSM} 21648^{\top}=\mathrm{CIP} 109928^{\top}\right)$.
\end{abstract}

K. Heckmann and H.-J. Schmidt described the genus Polynucleobacter to accommodate bacteria living as obligate endosymbionts in cells of freshwater ciliates affiliated with the genus Euplotes, and the species Polynucleobacter necessarius for obligate endosymbionts of Euplotes aediculatus (Heckmann \& Schmidt, 1987). Recently, a close phylogenetic relationship between such obligate endosymbionts and obligately free-living strains was demonstrated (Vannini et al., 2007). Consequently, the description of the genus Polynucleobacter and the species $P$. necessarius was emended by adding descriptions of free-living strains (Hahn et al., 2009). Due to the very pronounced differences in lifestyle of the closely related obligately endosymbiotic and obligately free-living strains, the placement of these organisms in the two subspecies $P$. necessarius subsp. necessarius (for endosymbionts of $E$. aediculatus and Euplotes harpa) and P. necessarius subsp. asymbioticus (for obligately free-living strains) was proposed (Hahn et al.,

Abbreviation: $\mathrm{OD}$, optical density.

The GenBank/EMBL/DDBJ accession number for the 16S rRNA gene sequence of strain MT-CBb6A5 ${ }^{\top}$ is FM208182.
2009). Furthermore, the species Polynucleobacter cosmopolitanus representing the second species within the genus Polynucleobacter was described recently (Hahn et al., 2010). This species accommodates, so far, exclusively free-living strains. The obligately free-living bacteria affiliated with these two species represent aerobic, chemo-organotrophic, non-motile bacteria. Investigations employing fluorescent in situ hybridization (FISH) probes specific for P. necessarius or $P$. cosmopolitanus demonstrated that the free-living strains representing these two taxa possess a planktonic lifestyle and contribute significantly to bacterioplankton in freshwater habitats (Hahn et al., 2005; Wu \& Hahn, 2006; Salcher et al., 2008). The highest contributions of $P$. necessarius and $P$. cosmopolitanus reported so far were about $60 \%$ and $8 \%$, respectively, of total bacterial cell numbers (Hahn et al., 2005, 2010). Numerous studies employing cultivation-independent methods for the exploration of bacterial diversity in freshwater, marine and terrestrial habitats revealed that bacteria of the genus Polynucleobacter are present in a broad variety of freshwater habitats (e.g. Hiorns et al., 1997; Crump et al., 1999; Crump \& Hobbie, 2005; Zwart et al., 2002; Burkert et al., 2003; Hahn 
et al., 2005; Grossart et al., 2008) but reports on their presence at off-shore marine and terrestrial sites are lacking.

In previous studies, a monophyletic cluster of strains (minimal 16S rRNA gene sequence similarity of $95.7 \%$, Hahn, 2003) including a sequence of an endosymbiotic $P$. necessarius strain (Springer et al., 1996) was described as
'Polynucleobacter necessarius cluster' (Zwart et al., 2002), which was later subdivided in four monophyletic subclusters designated A to D (Hahn, 2003). The previously emended species $P$. necessarius is equivalent to subcluster C (also known as subcluster PnecC), and the recently described species $P$. cosmopolitanus is equivalent to subcluster D (PnecD). Here we describe a strain affiliated with

Table 1. Traits characterizing strain MT-CBb6A5 ${ }^{\top}$ and strains of the previously described taxa $P$. necessarius subsp. asymbioticus and $P$. cosmopolitanus

Taxa: 1, Polynucleobacter rarus sp. nov. MT-CBb6A5 $5^{\mathrm{T}} ; 2$, P. necessarius subsp. asymbioticus ( $n=4$; data from Hahn et al., 2009); 3 , P. cosmopolitanus ( $n=5$; Hahn et al., 2010). Note that the subspecies $P$. necessarius subsp. necessarius lacks a sufficient phenotypic and chemotaxonomic description due to the lack of pure cultures. All taxa are non-motile, positive for catalase and oxidase activities, grow anaerobically on NSY medium $+0.8 \mathrm{mM}$ nitrate, assimilate pyruvic acid and do not assimilate L-serine. - , Negative; + , positive; $\mathrm{w}$, weakly positive; $+/-$, some strains positive and some strains negative; $+/ \mathrm{w}$, some strains positive and some strains weakly positive; w/-, some strains weakly positive and some strains negative.

\begin{tabular}{|c|c|c|c|}
\hline Characteristic & 1 & 2 & 3 \\
\hline Cell morphology & Straight rods & Straight or curved rods & Curved rods \\
\hline Nucleoids visible (DAPI) & Frequently & Rarely & Rarely \\
\hline Cell length $(\mu \mathrm{m})$ & $0.8-1.8$ & $0.5-2.9$ & $0.4-1.4$ \\
\hline Cell width $(\mu \mathrm{m})$ & $0.6-0.8$ & $0.3-0.5$ & $0.3-0.5$ \\
\hline Growth at $5{ }^{\circ} \mathrm{C}$ & - & + & $+1-$ \\
\hline Growth at $35{ }^{\circ} \mathrm{C}$ & - & $+1-$ & + \\
\hline $\mathrm{NaCl}$ tolerance $(\%, \mathrm{w} / \mathrm{v})$ & $0.3(\mathrm{w})$ & $0.3-0.5$ & $0.3-0.5$ \\
\hline Anaerobic growth on NSY medium & - & $+1-$ & + \\
\hline Growth in mineral medium with acetic acid and B12 & $\mathrm{w}$ & $\mathrm{w} /-$ & $\mathrm{w} /-$ \\
\hline \multicolumn{4}{|l|}{ Assimilation of: } \\
\hline Urea & - & $+1-$ & $+1-$ \\
\hline Thiosulfate & - & $+1-$ & $+1-$ \\
\hline Formic acid & - & $\mathrm{w} /-$ & - \\
\hline Glyoxylic acid & + & $\mathrm{w} /-$ & $\mathrm{w} /-$ \\
\hline Glycolic acid & $\mathrm{w}$ & - & - \\
\hline Acetic acid & + & + & + \\
\hline Oxalic acid & $\mathrm{w}$ & - & - \\
\hline Propionic acid & - & $+1-$ & $+/ \mathrm{w}$ \\
\hline Malonic acid & - & $+1-$ & $+1-$ \\
\hline Oxaloacetic acid & - & $+1-$ & + \\
\hline Malic acid & + & $+/ \mathrm{w}$ & + \\
\hline Succinic acid & + & + & + \\
\hline Fumaric acid & + & $+/ \mathrm{w}$ & + \\
\hline Levulinic acid & + & $\mathrm{w} /-$ & $\mathrm{w} /-$ \\
\hline Citric acid & - & - & $+1-$ \\
\hline D-Mannose & $\mathrm{w}$ & $\mathrm{w} /-$ & $\mathrm{w} /-$ \\
\hline D-Glucose & - & $\mathrm{w} /-$ & $\mathrm{w} /-$ \\
\hline D-Galacturonic acid & + & $\mathrm{w}$ & $+/ \mathrm{w}$ \\
\hline D-Galactose & - & $\mathrm{w} /-$ & w \\
\hline D-Lyxose & $\mathrm{w}$ & $\mathrm{w} /-$ & - \\
\hline D-Fructose & $\mathrm{w}$ & $\mathrm{w} /-$ & - \\
\hline D-Fucose & $\mathrm{w}$ & $\mathrm{w} /-$ & - \\
\hline D-Sorbitol & - & $\mathrm{w} /-$ & - \\
\hline L-Glutamate & - & $+1-$ & $\mathrm{w} /-$ \\
\hline L-Aspartate & - & $+1-$ & - \\
\hline L-Cysteine & $\mathrm{w}$ & $+/ \mathrm{w}$ & + \\
\hline L-Alanine & - & $\mathrm{w} /-$ & $+/ \mathrm{w}$ \\
\hline L-Asparagine & - & $\mathrm{w} /-$ & - \\
\hline Betaine & - & $\mathrm{w} /-$ & - \\
\hline DNA G $+\mathrm{C}$ content $(\mathrm{mol} \%)$ & 40.3 & $44-46$ & 44.9 \\
\hline
\end{tabular}


subcluster A (PnecA) and propose to establish for this strain the species Polynucleobacter rarus sp. nov. Note that this new species represents only a fraction of the highly diverse subcluster A of the 'Polynucleobacter necessarius cluster'.

\section{Isolation and characterization}

Strain MT-CBb6A5 ${ }^{\mathrm{T}}$ was isolated from Crystal Bog Lake (Newton et al., 2006) by using the filtration-acclimatization method (Hahn, 2003; Hahn et al., 2004). This isolation method includes a step of filtration through $0.2 \mu \mathrm{m}$ filters, which seems to contradict the cell dimensions of the cultivated strain presented below. However, variations of pore sizes of the filter or much smaller in situ cell sizes of the strain may be responsible for the passing of the ancestor cell through the filter. At the time of writing, only a single strain affiliated with subcluster $A$ of the ' $P$. necessarius cluster' has been isolated, while $>150$ and $>50$ strains of subcluster $\mathrm{C}(P$. necessarius $)$ and subcluster $\mathrm{D}(P$. cosmopolitanus), respectively, have been isolated (Hahn, 2003; Hahn et al., 2005, 2010; Watanabe et al., 2009). The isolation method for bacteria of the genus Polynucleobacter developed by Watanabe et al. (2009) uses a $0.8 \mu \mathrm{m}$ filtration step, whereas, in several isolation experiments, Hahn et al. $(2005,2009)$ replaced the filtration step by a dilution step (dilution-acclimatization method); thus, the singular isolation of a Polynucleobacter strain affiliated with subcluster A cannot exclusively be explained by the utilization of $0.2 \mu \mathrm{m}$ filters.

Initially, pure cultures of the strain in liquid NSY medium (Hahn et al., 2004) showed formation of flocks; however, this trait disappeared after some subcultivation steps. The investigated strain was routinely grown on NSY and R2A (Remel) medium with concentrations of $3 \mathrm{~g} \mathrm{l}^{-1}$; however, similar to previously investigated Polynucleobacter strains, the biomass yield of strain MT-CBb6A5 ${ }^{\mathrm{T}}$ on these media was much lower than that observed for other members of the family Burkholderiaceae. Growth at different

Table 2. Whole-cell fatty acid composition of strain MT-CBb6A5 ${ }^{\top}$ as compared with strains of $P$. necessarius subsp. asymbioticus and $P$. cosmopolitanus

Taxa: 1, Polynucleobacter rarus MT-CBb6A5 ${ }^{\mathrm{T}}$; 2, P. necessarius subsp. asymbioticus QLW-P1DMWA- ${ }^{\mathrm{T}}$ (data from Hahn et al., 2009); 3, P. necessarius ( $n=3$; Hahn et al., 2009); 4, P. cosmopolitanus MWH-MoIso2 $2^{\mathrm{T}}$ (Hahn et al., 2010); 5, P. cosmopolitanus ( $n=5$; Hahn et al., 2010). Values are percentages of the summed fatty acids named in the peak library of the MIDI system (contents $\geqslant 0.1 \%$ ). Strains were grown on R2A agar plates for $3-5$ days at $28{ }^{\circ} \mathrm{C}$. tr, Trace, may be detected or not in independent experiments.

\begin{tabular}{|c|c|c|c|c|c|}
\hline Fatty acid & 1 & 2 & 3 & 4 & 5 \\
\hline \multicolumn{6}{|l|}{ Saturated } \\
\hline $\mathrm{C}_{12: 0}$ & 3.0 & 3.4 & $3.4-5.5$ & - & - \\
\hline $\mathrm{C}_{14: 0}$ & 0.4 & 0.9 & $0.3-1.2$ & 0.7 & $0.6-2.3$ \\
\hline $\mathrm{C}_{15: 0}$ & $\operatorname{tr}$ & 0.3 & $\operatorname{tr}$ & 0.2 & $\operatorname{tr}$ \\
\hline $\mathrm{C}_{16: 0}$ & 19.8 & 22.2 & $15.5-33.5$ & 15.4 & $11.0-15.4$ \\
\hline $\mathrm{C}_{17: 0}$ & 0.3 & - & $\operatorname{tr}$ & - & $\operatorname{tr}$ \\
\hline $\mathrm{C}_{18: 0}$ & 0.5 & 1.2 & $0.5-2.6$ & 0.8 & $0.5-1.1$ \\
\hline \multicolumn{6}{|l|}{ Unsaturated } \\
\hline $\mathrm{C}_{14: 1} \omega 5 c$ & 0.2 & - & $0-0.6$ & 0.6 & $0-0.6$ \\
\hline $\mathrm{C}_{15: 1} \omega 8 c$ & 0.2 & - & - & - & - \\
\hline $\mathrm{C}_{15: 1} \omega 6 c$ & 0.3 & - & $0-0.6$ & - & - \\
\hline $\mathrm{C}_{16: 1} \omega 5 c$ & 0.5 & 0.9 & $0-0.9$ & 0.3 & $0.3-1.1$ \\
\hline $\mathrm{C}_{17: 1} \omega 6 c$ & $\operatorname{tr}$ & - & - & 0.5 & $0-0.7$ \\
\hline $\mathrm{C}_{18: 1} \omega 9 c$ & $\operatorname{tr}$ & - & $0-0.4$ & 0.3 & $0-2.0$ \\
\hline $\mathrm{C}_{18: 1} \omega 7 c$ & 21.8 & 12.9 & $0.25-20.4$ & 28.7 & $28.7-38.1$ \\
\hline $\mathrm{C}_{18: 1} \omega 5 c$ & - & - & - & 0.2 & $\operatorname{tr}$ \\
\hline 11-Methyl $C_{18: 1} \omega 7 c$ & 7.5 & 3.1 & $0.2-8.1$ & 3.7 & $0.4-3.7$ \\
\hline 10-Methyl $C_{19: 0}$ & 0.4 & - & - & 0.7 & $0-0.7$ \\
\hline \multicolumn{6}{|l|}{ Hydroxylated } \\
\hline $\mathrm{C}_{12: 0} 2-\mathrm{OH}$ & - & 2.5 & $1.3-2.5$ & - & - \\
\hline $\mathrm{C}_{12: 0} 3-\mathrm{OH}$ & - & - & - & 11.1 & $7.1-11.2$ \\
\hline $\mathrm{C}_{16: 0} 3-\mathrm{OH}$ & 0.3 & - & - & - & - \\
\hline \multicolumn{6}{|l|}{ Summed features } \\
\hline $1\left(\mathrm{C}_{12: 0}\right.$ ALDE? $)$ & 1.8 & 0.4 & $0.4-2.1$ & 0.1 & $\operatorname{tr}$ \\
\hline 2 (including $\mathrm{C}_{14: 0} 3-\mathrm{OH}$ ) & 6.9 & 9.6 & $8.4-9.9$ & 0.6 & $0.6-3.9$ \\
\hline 3 (including $\mathrm{C}_{16: 1} \omega 7 c$ ) & 35.9 & 41.3 & $35.6-45.0$ & 34.7 & $31.5-36.5$ \\
\hline 7 (including $\mathrm{C}_{19: 1} \omega 6 c$ ) & - & 0.4 & $0.2-2.0$ & 1.5 & $0-1.5$ \\
\hline
\end{tabular}




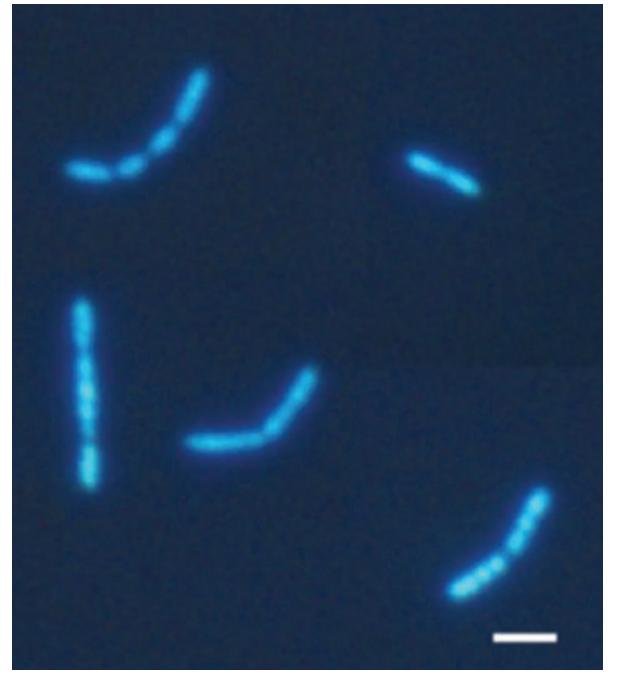

Fig. 1. Epifluorescence microscopic images of cells of strain MT$\mathrm{CBb} 6 \mathrm{~A} 5^{\top}$ stained with the nucleic acid dye $4^{\prime}, 6$-diamidino-2phenylindole (DAPI). Note that the image shows a collection of cells showing multiple nucleoids, which is a trait not shared by all cells present in cultures of the strain. The fraction of cells showing this trait is variable and seems to be influenced by the age of the culture. Bar, $2 \mu \mathrm{m}$.

temperatures and growth under anoxic conditions in an anaerobic chamber were examined on NSY agar or on NSY medium supplemented with nitrate $(0.8 \mathrm{mM}) . \mathrm{NaCl}$ tolerance was determined using NSY agar supplemented with different $\mathrm{NaCl}$ concentrations $(0,0.1,0.2,0.3,0.4,0.5$, $0.6,0.7,1.0,1.25,1.5,1.75$ and $2.0 \%, \mathrm{w} / \mathrm{v})$. The temperature range supporting growth was tested on NSY agar plates exposed to different temperatures $(5,15,20,25$, 30 and $\left.35^{\circ} \mathrm{C}\right)$. Utilization of various substrates was investigated in the same way as for previously described species of the genus Polynucleobacter (Hahn et al., 2009, 2010). Briefly, growth enabled by utilization of a specific substrate was determined by comparison of optical density (OD) established in liquid one-tenth-strength NSY medium $\left(0.3 \mathrm{~g} \mathrm{l}^{-1}\right)$ with and without $0.5 \mathrm{~g}$ test substance $\mathrm{l}^{-1}$. OD differences of $<10 \%$, of $10-50 \%$ and of $>50 \%$ of the OD established on the medium without test substance were scored after 10 days of growth as no utilization (-), weak utilization (w) and good utilization $(+)$, respectively.

Sequencing and phylogenetic analyses of 16S rRNA genes were performed as described previously (Hahn, 2003; Hahn et al., 2005). Neighbour-joining trees were calculated by using the software MEGA4 (Tamura et al., 2007) and maximum-likelihood trees were generated by using the RaxML web server (Stamatakis et al., 2008). The G+C content of DNA was determined as described by Tóth et al. (2008). Fatty acid methyl esters (FAMEs) were obtained as described by Kämpfer \& Kroppenstedt (1996) and separated by a gas chromatograph (model 6890, Hewlett Packard). Peaks were automatically computed using the
Table 3. Discriminative characteristics separating strain MT$\mathrm{CBb} 6 \mathrm{~A} 5^{\top}$ from $P$. necessarius subsp. asymbioticus and $P$. cosmopolitanus

Taxa: 1, Polynucleobacter rarus sp. nov. MT-CBb6A5 ${ }^{\mathrm{T}} ; 2, \quad P$. necessarius subsp. asymbioticus $[n=3$ (fatty acids) or 4 (phenotypic features); data from Hahn et al., 2009]; 3, P. cosmopolitanus $[\mathrm{n}=3$ (phenotypic features) or 5 (fatty acids); Hahn et al., 2010]. P. rarus sp. nov. differs from the obligately endosymbiotic $P$. necessarius subsp. necessarius in its free-living lifestyle. Note that only an incomplete phenotypic and chemotaxonomic description of P. necessarius subsp. necessarius is available because of the lack of pure cultures. - , Negative; + , positive.

\begin{tabular}{|lccc|}
\hline Characteristic & $\mathbf{1}$ & $\mathbf{2}$ & $\mathbf{3}$ \\
\hline${\text { Nucleoids visible }(\mathrm{DAPI})^{\star}}^{\text {Cell width }(\mu \mathrm{m})}$ & Frequently & Rarely & Rarely \\
Utilization of glycolic acid & $0.6-0.8$ & $0.3-0.5$ & $0.3-0.5$ \\
Utilization of oxalic acid & + & - & - \\
$\mathrm{C}_{12: 0}$ & + & - & - \\
$\mathrm{C}_{15: 1} \omega 8 c$ & + & + & - \\
$\mathrm{C}_{12: 0} 2-\mathrm{OH}$ & + & - & - \\
$\mathrm{C}_{16: 0} 3-\mathrm{OH}$ & - & + & - \\
DNA G+C content (mol\%) & 40.3 & $44-46$ & 44.9 \\
\hline
\end{tabular}

${ }^{\star}$ Staining with a fluorescent nucleic acid dye (e.g. DAPI) and epifluorescence microscopic observation.

Microbial Identification standard software package (Sasser, 1990).

The results of the phenotypic and chemotaxonomic characterization of strain $\mathrm{MT}-\mathrm{CBb} 6 \mathrm{~A} 5^{\mathrm{T}}$ are presented in Tables 1 and 2. The strain differs from strains of $P$. necessarius subsp. asymbioticus and P. cosmopolitanus in the relatively large cell widths, and in the frequently observable presence of multiple nucleoid structures (Fig. 1). Such structures were reported for endosymbiotic strains recently assigned to the subspecies $P$. necessarius subsp. necessarius and the genus name refers to them (Heckmann \& Schmidt, 1987); however, this feature was only rarely observed in other free-living Polynucleobacter strains (Hahn, 2003; Hahn et al., 2009, 2010). Furthermore, the investigated strain differed from both previously described taxa in the ability to utilize oxalic and glycolic acids (Table 3). Strain MT-CBb6A5 ${ }^{\mathrm{T}}$ showed visible growth under anoxic conditions only on NSY medium supplemented with increased concentrations of nitrate and not on standard NSY medium. This observation could result from nitrate respiration.

The $\mathrm{G}+\mathrm{C}$ content of the DNA of strain MT-CBb6A5 ${ }^{\mathrm{T}}$ was $40.3 \mathrm{~mol} \%$, which is substantially lower than those of $P$. necessarius strains (44-46 mol\%) and the P. cosmopolitanus type strain (44.9 mol\%). Whole-cell fatty acids of strain MT-CBb6A5 ${ }^{\mathrm{T}}$ were dominated by the unsaturated components $\mathrm{C}_{16: 1} \omega 7 c$ (feature 3), $\mathrm{C}_{18: 1} \omega 7 c$ and 11-methyl $\mathrm{C}_{18: 1} \omega 7 c$ and straight chain $\mathrm{C}_{16: 0}$. Relatively high amounts 
of feature 2 , including $\mathrm{C}_{14: 0} 3-\mathrm{OH}$, were also detected. The pattern, consisting of these major components and a high number of minor compounds, resembled those of the two other species of the genus Polynucleobacter, confirming the membership of the strain in this genus. The novel strain contained $\mathrm{C}_{12: 0}$, a feature differentiating it from $P$. necessarius subsp. asymbioticus. Furthermore, strain MT$\mathrm{CBb} 6 \mathrm{~A} 5^{\mathrm{T}}$ was characterized by the presence of low amounts of $\mathrm{C}_{16: 0} 3-\mathrm{OH}$ and $\mathrm{C}_{15: 1} \omega 8 c$, which were lacking in the other Polynucleobacter strains. Instead, strain MT$\mathrm{CBb}^{2} 5^{\mathrm{T}}$ was devoid of $\mathrm{C}_{12: 0} 2-\mathrm{OH}$ and $\mathrm{C}_{12: 0} 3-\mathrm{OH}$, which are present in P. necessarius subsp. asymbioticus and $P$. cosmopolitanus, respectively.

\section{Phylogeny}

The phylogenetic analysis of the almost complete $16 \mathrm{~S}$ rRNA gene sequence of strain MT-CBb6 $5^{\mathrm{T}}$ demonstrated a close relationship with the two previously described species of the genus Polynucleobacter but also demonstrated a clustering separate from those two taxa (Fig. 2). Note that a more detailed phylogenetic analysis including the $16 \mathrm{~S}$ rRNA gene and the 16S-23S ITS sequences of strain MTCBb6A5 ${ }^{\mathrm{T}}$ was published previously (Hahn et al., 2010). The sequence similarities between 16S rRNA genes of strain MT-CBb6A5 $5^{\mathrm{T}}$ and the type strain of $P$. necessarius subsp. asymbioticus, a sequence representing $P$. necessarius subsp. necessarius 'E24', and the type strain of $P$. cosmopolitanus were $96.0 \%, 95.6 \%$ and $96.0 \%$, respectively.

\section{Ecology of Polynucleobacter rarus sp. nov.}

Despite the lack of both quantitative in situ data and systematic surveys on the distribution of $P$. rarus sp. nov., it seems that this taxon represents, in contrast to $P$. necessarius subsp. asymbioticus and $P$. cosmopolitanus, a rare species. A BLAST search with the almost complete $16 \mathrm{~S}$ rRNA gene sequence of strain MT-CBb6A5 ${ }^{\mathrm{T}}$ as a query resulted in only nine hits (all affiliated with subcluster A of the 'Polynucleobacter cluster') with sequence similarities
$>97 \%$. Most of these hits represent environmental sequences of uncultured bacteria. The closest hit (accession number FR667321), representing a bacterium from a high mountain lake located in the Pyrenees, Spain (M. Bartrons, unpublished data), shares with $P$. rarus sp. nov. a sequence similarity of only $99.5 \%$. The other eight sequences originate from the Adirondack lakes, New York (accession number EF520438, Percent et al., 2008), the estuaries Chesapeake Bay and Delaware Bay (accession numbers EU801586 and EU800645, Shaw et al., 2008), from Arctic Toolik Lake (accession number AF534432, Crump et al., 2003), from Lake Shirakoma, Japan (accession numbers AB599841 and AB599847, K. Watanabe, Y. Ishii, N. Komatsu, T. Honma, R. Miyata, N. Noda, Y. Sekiguchi, S. Hayashi and A. Imai, unpublished data) and from Crystal Bog Lake (two identical sequences with accession numbers AY792238 and AY792240, Newton et al., 2006). The latter two sequences share with strain MT-CBb6A5 ${ }^{\mathrm{T}}$ the same origin but only sequence similarities of $97.7 \%$. Similar BLAST searches with the type strains of of $P$. cosmopolitanus and P. necessarius subsp. asymbioticus resulted in $>100$ hits representing environmental sequences and cultivated strains with sequence similarities ranging from $98.5 \%$ to $100 \%$, respectively. Thus, the under representation of strains affiliated to subcluster A relative to members of other subclusters in Polynucleobacter culture collections seems to result mainly from a relative rareness of the taxon in the environment.

The origin of strain MT-CBb6A5 $5^{\mathrm{T}}$ and the closest related taxa from the water column of freshwater lakes or from rivers and estuaries receiving water from freshwater lakes seems to indicate that strains affiliated with $P$. rarus sp. nov. dwell in the water column of freshwater systems as free-living planktonic bacteria. Such a lifestyle was demonstrated for $P$. necessarius subsp. asymbioticus and P. cosmopolitanus previously (Hahn et al., 2005; Wu \& Hahn, 2006). On the other hand, the initial observation of flock formation in liquid cultures could hint at an attached lifestyle of the strain. Dystrophic Crystal Bog Lake, from

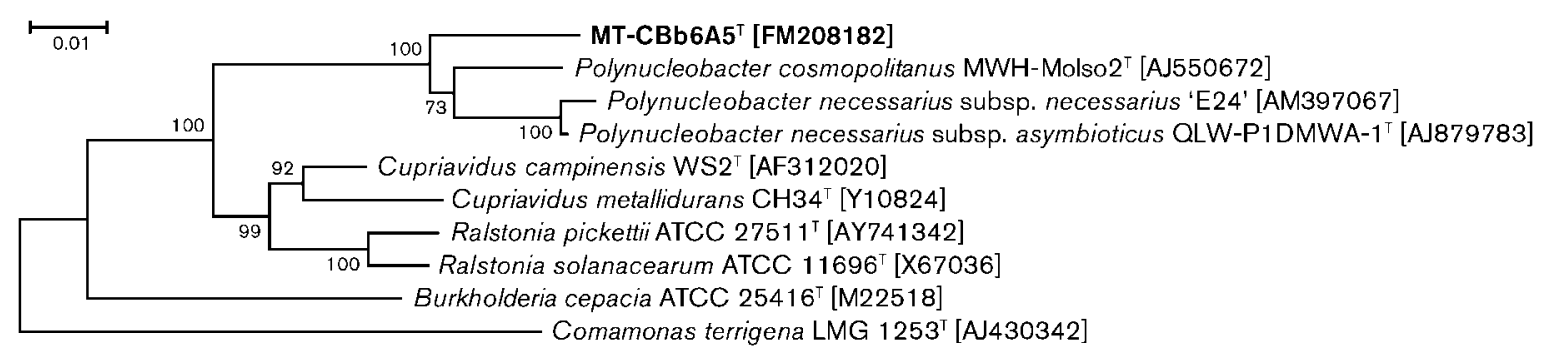

Fig. 2. Neighbour-joining tree based on almost complete 16S rRNA gene sequences, reconstructing the phylogenetic position of strain MT-CBb6A5 ${ }^{\top}$. Bar, 0.01 substitutions per nucleotide position. Note that previous analysis of the phylogeny of the genus Polynucleobacter, which analysed 16S rRNA gene sequences and 16S-23S ITS sequences by the neighbour-joining and maximum-likelihood method (Hahn et al., 2010), confirmed the phylogenetic position of strain MT-CBb6A5 ${ }^{\top}$ in the Polynucleobacter clade. 
which the type strain of $P$. rarus sp. nov. was isolated, is a shallow, acidic lake strongly influenced by the surrounding bog, which results in a relatively high concentration of allochtonous humic substances in the water of the lake (Newton et al., 2006). A preference of P. rarus sp. nov. for acidic habitats is likely; however, the small dataset available for this taxon enables only preliminary conclusions.

Results from the phylogenetic analysis and chemotaxonomic investigations demonstrated the affiliation of strain MT-CBb6A5 ${ }^{\mathrm{T}}$ to the genus Polynucleobacter (Tables 1 and 2, Fig. 2) but also revealed pronounced differences between this strain and strains affiliated with previously described species of the genus Polynucleobacter (Table 3). The 16S rRNA gene sequence similarities determined between strain MT-CBb6A $5^{\mathrm{T}}$ and strains representing the two P. necessarius subspecies as well as $P$. cosmopolitanus of $<97 \%$ clearly indicate that the investigated strain represents a new species of the genus Polynucleobacter. Therefore, we propose to establish the species Polynucleobacter rarus sp. nov. with strain MT-CBb6A5 $5^{\mathrm{T}}$ as the type strain. Note that we do not propose to tentatively include all strains of the so-called subcluster A (PnecA) in this new species. This subcluster represents, in contrast to subclusters PnecC $(P$. necessarius) and PnecD (P. cosmopolitanus), a phylogenetically more diverse subcluster, which makes it more likely than the other two subclusters to consist of more than one species.

\section{Description of Polynucleobacter rarus sp. nov.}

Polynucleobacter rarus (ra'rus. L. masc. adj. rarus rare, referring to the observation that this species represents a rare species, in contrast to the previously described species of the genus Polynucleobacter).

Straight, non-motile rods, $0.8-1.8 \mu \mathrm{m}$ in length and 0.6$0.8 \mu \mathrm{m}$ in width. Staining with nucleic acid dyes results in the microscopical visibility of multiple nucleoids in a significant fraction of cells. Chemo-organotrophic and aerobic; anaerobic growth in the presence of nitrate. Can be cultivated on NSY and R2A medium. Colonies grown on NSY agar are unpigmented, circular and convex with smooth surface. Mesophilic; no growth at $5{ }^{\circ} \mathrm{C}$ or $35^{\circ} \mathrm{C}$. Grows without $\mathrm{NaCl}$. Maximum $\mathrm{NaCl}$ concentration tolerated is $0.3 \%(\mathrm{w} / \mathrm{v})$. Oxidase- and catalase-positive. Utilizes glyoxylate, glycolate, acetate, oxalate, pyruvate, malate, succinate, fumarate, levulinate, D-mannose, D-galacturonic acid, D-lyxose, D-fructose, D-fucose and $\mathrm{L}$-cysteine when these substrates are provided in a medium containing low amounts of NSY. Does not utilize formate, propionate, malonate, oxaloacetate, citrate, D-glucose, D-galactose, D-sorbitol, L-glutamate, L-aspartate, L-alanine, L-serine, L-asparagine or betaine. Major cellular fatty acids are $\mathrm{C}_{16: 0}, \mathrm{C}_{18: 1} \omega 7 c, 11$-methyl $\mathrm{C}_{18: 1} \omega 7 c$, feature 3 (including $\mathrm{C}_{16: 1} \omega 7 c$ ), and feature 2 (including $\mathrm{C}_{14: 0}$ 3-OH). The DNA G $+\mathrm{C}$ content of the type strain is $40.3 \mathrm{~mol} \%$. The sole cultivated strain currently representing this species is a free-living strain.
The type strain is MT-CBb6A5 ${ }^{\mathrm{T}}\left(=\mathrm{DSM} 21648^{\mathrm{T}}=\mathrm{CIP}\right.$ $109928^{\mathrm{T}}$ ), isolated from the water column (pelagic zone) of Crystal Bog Lake in Wisconsin, USA.

\section{Acknowledgements}

We thank K. McMahon for providing a water sample from Crystal Bog Lake. We appreciate the determination of the $G+C$ content by P. Schumann, DSMZ, and of the fatty acids by R.M. Kroppenstedt, DSMZ. This study was supported by the Austrian Science Fund (Project P19853 granted to M.W.H.).

\section{References}

Burkert, U., Warnecke, F., Babenzien, D., Zwirnmann, E. \& Pernthaler, J. (2003). Members of a readily enriched proteobacterial clade are common in surface waters of a humic lake. Appl Environ Microbiol 69, 6550-6559.

Crump, B. C. \& Hobbie, J. E. (2005). Synchrony and seasonality in bacterioplankton communities of two temperate rivers. Limnol Oceanogr 50, 1718-1729.

Crump, B. C., Armbrust, E. V. \& Baross, J. A. (1999). Phylogenetic analysis of particle-attached and free-living bacterial communities in the Columbia river, its estuary, and the adjacent coastal ocean. Appl Environ Microbiol 65, 3192-3204.

Crump, B. C., Kling, G. W., Bahr, M. \& Hobbie, J. E. (2003). Bacterioplankton community shifts in an arctic lake correlate with seasonal changes in organic matter source. Appl Environ Microbiol 69, 2253-2268.

Grossart, H. P., Jezbera, J., Hornak, K., Hutalle, K. M. L., Buck, U. \& Simek, K. (2008). Top-down and bottom-up induced shifts in bacterial abundance, production and community composition in an experimentally divided humic lake. Environ Microbiol 10, 635-652.

Hahn, M. W. (2003). Isolation of strains belonging to the cosmopolitan Polynucleobacter necessarius cluster from freshwater habitats located in three climatic zones. Appl Environ Microbiol 69, 5248-5254.

Hahn, M. W., Stadler, P., Wu, Q. L. \& Pöckl, M. (2004). The filtrationacclimatization method for isolation of an important fraction of the not readily cultivable bacteria. J Microbiol Methods 57, 379-390.

Hahn, M. W., Pöckl, M. \& Wu, Q. L. (2005). Low intraspecific diversity in a polynucleobacter subcluster population numerically dominating bacterioplankton of a freshwater pond. Appl Environ Microbiol 71, 4539-4547.

Hahn, M. W., Lang, E., Brandt, U., Wu, Q. L. \& Scheuerl, T. (2009). Emended description of the genus Polynucleobacter and the species Polynucleobacter necessarius and proposal of two subspecies, $P$. necessarius subsp. necessarius subsp. nov. and P. necessarius subsp. asymbioticus subsp. nov. Int J Syst Evol Microbiol 59, 2002-2009.

Hahn, M. W., Lang, E., Brandt, U., Lünsdorf, H., Wu, Q. L. \& Stackebrandt, E. (2010). Polynucleobacter cosmopolitanus sp. nov., free-living planktonic bacteria inhabiting freshwater lakes and rivers. Int J Syst Evol Microbiol 60, 166-173.

Heckmann, K. \& Schmidt, H. J. (1987). Polynucleobacter necessarius gen. nov., sp. nov., an obligately endosymbiotic bacterium living in the cytoplasm of Euplotes. Int J Syst Bacteriol 37, 456-457.

Hiorns, W. D., Methé, B. A., Nierzwicki-Bauer, S. A. \& Zehr, J. P. (1997). Bacterial diversity in Adirondack mountain lakes as revealed by $16 \mathrm{~S}$ rRNA gene sequences. Appl Environ Microbiol 63, 29572960 . 
Kämpfer, P. \& Kroppenstedt, R. M. (1996). Numerical analysis of fatty acid patterns of coryneform bacteria and related taxa. Can $J$ Microbiol 42, 989-1005.

Newton, R. J., Kent, A. D., Triplett, E. W. \& McMahon, K. D. (2006). Microbial community dynamics in a humic lake: differential persistence of common freshwater phylotypes. Environ Microbiol 8, 956-970.

Percent, S. F., Frischer, M. E., Vescio, P. A., Duffy, E. B., Milano, V., McLellan, M., Stevens, B. M., Boylen, C. W. \& Nierzwicki-Bauer, S. A. (2008). Bacterial community structure of acid-impacted lakes: what controls diversity? Appl Environ Microbiol 74, 1856-1868.

Salcher, M. M., Pernthaler, J., Zeder, M., Psenner, R. \& Posch, T. (2008). Spatio-temporal niche separation of planktonic Betaproteobacteria in an oligo-mesotrophic lake. Environ Microbiol 10, 2074-2086.

Sasser, M. (1990). Identification of bacteria by gas chromatography of cellular fatty acids, MIDI Technical Note 101. Newark, DE: MIDI Inc.

Shaw, A. K., Halpern, A. L., Beeson, K., Tran, B., Venter, J. C. \& Martiny, J. B. (2008). It's all relative: ranking the diversity of aquatic bacterial communities. Environ Microbiol 10, 2200-2210.

Springer, N., Amann, R., Ludwig, W., Schleifer, K. H. \& Schmidt, H. (1996). Polynucleobacter necessarius, an obligate bacterial endosymbiont of the hypotrichous ciliate Euplotes aediculatus, is a member of the beta-subclass of Proteobacteria. FEMS Microbiol Lett 135, 333336.
Stamatakis, A., Hoover, P. \& Rougemont, J. A. (2008). A rapid bootstrap algorithm for the RAxML Web servers. Syst Biol 57, 758-771.

Tamura, K., Dudley, J., Nei, M. \& Kumar, S. (2007). MEGA4: molecular evolutionary genetics analysis (MEGA) software version 4.0. Mol Biol Evol 24, 1596-1599.

Tóth, E. M., Kéki, Z., Homonnay, Z. G., Borsodi, A. K., Márialigeti, K. \& Schumann, P. (2008). Nocardioides daphniae sp. nov., isolated from Daphnia cucullata (Crustacea: Cladocera). Int J Syst Evol Microbiol 58, 78-83.

Vannini, C., Pöckl, M., Petroni, G., Wu, Q. L., Lang, E., Stackebrandt, E., Schrallhammer, M., Richardson, P. M. \& Hahn, M. W. (2007). Endosymbiosis in statu nascendi: close phylogenetic relationship between obligately endosymbiotic and obligately free-living Polynucleobacter strains (Betaproteobacteria). Environ Microbiol 9, 347-359.

Watanabe, K., Komatsu, N., Ishii, Y. \& Negishi, M. (2009). Effective isolation of bacterioplankton genus Polynucleobacter from freshwater environments grown on photochemically degraded dissolved organic matter. FEMS Microbiol Ecol 67, 57-68.

Wu, Q. L. \& Hahn, M. W. (2006). Differences in structure and dynamics of Polynucleobacter communities in a temperate and a subtropical lake, revealed at three phylogenetic levels. FEMS Microbiol Ecol 57, 67-79.

Zwart, G., Crump, B. C., Kamst-van Agterveld, M. P., Hagen, F. \& Han, S.-K. (2002). Typical freshwater bacteria: an analysis of available $16 \mathrm{~S}$ rRNA gene sequences from plankton of lakes and rivers. Aquat Microb Ecol 28, 141-155. 